\title{
CHINY
}

\section{Kamil Smogorzewski}

\section{AIIB I NDB - FUNDAMENTY GEOPOLITYCZNEJ STRATEGII CHIŃSKIEJ REPUBLIKI LUDOWEJ}

\section{Wprowadzenie}

Koniec drugiej dekady XXI w., zgodnie z przewidywaniami wielu komentatorów światowej sceny politycznej, będzie również początkiem końca powstałego po zakończeniu zimnej wojny ładu światowego. Ładu, który ustanowiły Stany Zjednoczone i dzięki oparciu go na systemie z Bretton Woods - również kontrolowały, wpływały na niego i kreowały go. W ostatnich latach, co pokazał kryzys finansowy 2007/2008, USA nie dysponują już na tyle potężnymi narzędziami, aby jednogłośnie projektować gospodarczą architekturę świata. Co więcej, w Azji w ciągu kilkudziesięciu lat wyrósł najpotężniejszy przeciwnik, z jakim jedyne światowe supermocarstwo miało kiedykolwiek do czynienia - Chińska Republika Ludowa. W 2015 r., po raz pierwszy od XIX w., zachwiana została bezdyskusyjna dotąd dominacja Stanów Zjednoczonych w sferze gospodarczej - ChRL zdołała wysunąć się na pierwsze miejsce pod względem PKB, liczonego według parytetu siły nabywczej.

Czas chińskiej prosperity opartej na taniej produkcji i eksporcie tanich towarów dobiega jednak końca. Aby zapewnić dalszy dynamiczny rozwój, niezbędne będzie uzyskanie kontroli nad handlem kontynentalnym. Przynajmniej do czasu zakończenia morskiej dominacji USA. Aby do tego doszło, konieczne będzie dalsze osłabienie pozycji Stanów Zjednoczonych poprzez stopniowe przejmowanie kontroli nad globalnym rynkiem finansowym i walutowym. Artykuł stanowi weryfikację hipotezy, w myśl której Chińska Republika Ludowa, posługując się dwiema strategicznymi instytucjami - Azjatyckim Bankiem Inwestycji Infrastrukturalnych (AIIB) oraz Nowym Bankiem Rozwoju (NDB) - może osiągnąć lądową 
dominację gospodarczą. Konieczne było określenie podstawowych założeń wstępnych: w ciągu kilkunastu kolejnych lat nie wybuchnie otwarty konflikt zbrojny na skalę światową; nie nastąpi kryzys polityczny w Chinach; Stany Zjednoczone nie zrezygnują z dominacji nad morskimi szlakami handlowymi; nie nastąpi przeorientowanie polityki zagranicznej Stanów Zjednoczonych w sposób, który mógłby zachwiać istniejącymi ramami instytucjonalnymi w sferze finansowej i gospodarczej.

\section{Jakościowa zmiana polityki zagranicznej Chin}

Państwo Środka przez co najmniej dwadzieścia ostatnich lat prowadziło politykę w największym stopniu skierowaną na własny rozwój i niechętnie angażowało się w rolę choćby regionalnego mocarstwa ${ }^{1}$, uczestnicząc jedynie w projektach regionalnych, z czego głównymi są: Azjatycki Bank Rozwoju (ADB), ASEAN + 3 (APT), oraz w światowych instytucjach gospodarczych i finansowych, takich jak Światowa Organizacja Handlu (WTO) czy Międzynarodowy Fundusz Walutowy (IMF) i Bank Światowy (WB). W momencie przejęcia rządów przez Xi Jinpinga zauważalne jest odejście od polityki względnego izolacjonizmu, również w sferze gospodarczej, poprzez intensyfikację projektów ogólnoświatowych, których głównymi twórcami są właśnie Chiny².

Chiny w swej naturze, a jasne jest to dla większości badaczy cywilizacji chińskiej $^{3}$, poza pewnymi wyjątkami nie były skłonne do prowadzenia otwartej polityki ekspansywnej. Nie robiły tego z całą pewnością od czasów rozpoczęcia polityki kolonialnej przez europejskie mocarstwa. Tym bardziej istotne są powody zmiany

1 Zheng Wang, China's Institution Building. Leading the Way to Asian Integration, „Georgetown Journal of Asian Affairs", Spring/Summer 2015, s. 16.

2 Obecną ekspansję Chin, zwłaszcza w kontekście dominacji w Europie w interesujący sposób przedstawił Jan Sulmicki. Odwołując się do metody historycznej, dowodzi, że mamy do czynienia z czwartą próbą supremacji Chin w dziejach, co dalej nazywa „trendem milenijnym” - zmianą dokonującą się raz na kilkaset lat. W przeciwieństwie do zmian w ciągu ostatnich kilku stuleci, które polegały na wewnętrznych walkach o dominację w obszarze cywilizacji europejskiej, obecna zmiana pociąga za sobą również zmianę cywilizacyjną, ze wszystkimi tego konsekwencjami. Patrz: Jan Sulmicki, Chiny umacniają dominująca pozycję w gospodarce światowej, „Zeszyty Naukowe Akademii Vistula" 2015, nr 43 (3), s. 33-44.

${ }^{3}$ Odwołuję się tu do najpowszechniejszego obecnie podziału cywilizacji światowych, dokonanego przez Samuela Huntingtona na początku lat 90. w dziele Zderzenie cywilizacji i nowy kształt ładu światowego. Patrz: Samuel P. Huntington, Zderzenie cywilizacji i nowy kształt ładu światowego, przekł. Hanna Janowska, Warszawskie Wydawnictwo Literackie MUZA SA, Warszawa 2006; lepiej jednak rdzeń cywilizacji chińskiej oddają badania nie mniej ważnego uczonego, Feliksa Konecznego. Patrz: Feliks Koneczny, O ład w historii, Wydawnictwo Michalineum, Warszawa 1991. 
stylu prowadzenia polityki zagranicznej. Najważniejsze z nich można pogrupować w trzech obszarach: wewnętrznym, regionalnym oraz międzynarodowym.

Wewnętrzny wymiar decyzji o wyjściu poza dotychczasowe działania sensu stricto defensywne na arenie międzynarodowej mają ścisły związek z występowaniem ogromnych nierówności pomiędzy poszczególnymi chińskimi prowincjami. Ocena działań poprzedniego przewodniczącego Chińskiej Republiki Ludowej, Hu Jintao, w zwalczaniu dysproporcji społeczno-gospodarczych nie jest dobra ${ }^{4}$. O ile wschodnia część kraju, ze względu na otwarcie morskie dokonane przez Deng Xiaopinga wykazuje relatywnie wysoki poziom rozwoju, centralna i zachodnia nadal pozostają w dużej mierze zacofane. Tworzenie pełnej infrastruktury lądowej, więc szlaków drogowych, kolejowych i lotniczych od wschodnich Chin rozpoczynając, aż na wschodniej Europie kończąc, jest częścią planu mobilizacji rozwojowej zachodnich i centralnych prowincji. Działanie to jest niezbędne w celu utrzymania wysokiego tempa rozwoju gospodarczego, z wykorzystaniem własnych technologii (wymyślonych, zakupionych lub pozyskanych wcześniej z różnych źródeł), a przede wszystkim - własnego kapitału pochodzącego $\mathrm{z}$ rezerw ${ }^{5}$, sięgających ponad 3 bln dolarów ${ }^{6}$.

Drugą niezwykle istotną kwestią jest dywersyfikacja źródeł surowców energetycznych. Chiny, będące obecnie drugim największym na świecie konsumentem energii (15\%), ponad połowę zapotrzebowania na ropę naftową i ponad $30 \%$ zapotrzebowania na gaz ziemny pokrywają importem ${ }^{7}$. W 2012 r. wydana została tak zwana Biała Księga Energetyczna, w której jasno napisane jest, że Chińska Republika Ludowa dostawców surowców energetycznych ma poszukiwać wszędzie tam, gdzie tylko surowce owe do kupna są dostępne ${ }^{8}$. Dostawy kazachskiej czy azerskiej ropy naftowej z użyciem własnych ropociągów będą zdecydowanie bardziej bezpieczne. Rosja nie jest mile widzianym pośrednikiem.

Wymiar regionalny odnosi się już bezpośrednio do chęci uzyskania bezsprzecznej pozycji mocarstwa regionalnego w Azji oraz do potrzeb kontynentu azjatyckiego, łącznie z potrzebami samych Chin. Brak trwałych struktur łączących większość krajów tego coraz ważniejszego z perspektywy globalnej gospodarki i finansów obszaru oraz duże zróżnicowanie krajów - zarówno pod względem stosowanego

\footnotetext{
${ }^{4}$ Alice Ekman, China: Setting the Agenda(s)?, European Union Institute for Security Studies, „Issue Brief” 2015, nr 4, s. 1.

5 Justyna Szczudlik-Tatar, Damian Wnukowski, Azjatycki Bank Inwestycji Infrastrukturalnych: szanse dla polskiego biznesu, „Biuletyn PISM” 2015, nr 52 (1289), s. 1-2.

${ }^{6}$ Rezerwy walutowe Chin wzrosty najmocniej od 3 lat, https://www.bankier.pl/wiadomosc/Rezerwy-walutowe-Chin-wzrosly-najmocniej-od-3-lat-7515521.html [dostęp 24 listopada 2017].

7 Bogdan Góralczyk, Geostrategia energetyczna Chin, http://cse.ibngr.pl/geostrategia-energetyczna-chin/ [dostęp 10 stycznia 2014].

8 Tamże.
} 
modelu ekonomicznego, jak i formy rządów - powoduje, że plany Chin mogą być o wiele trudniejsze do zrealizowania, niż pierwotnie zakładano. Podstawowym problemem mogą się okazać działania Japonii jako głównego rywala Pekinu $\mathrm{w}$ regionie ${ }^{9}$ i oczywiście jednego z najważniejszych strategicznych partnerów USA. Zaszłości historyczne w dalszym ciągu uniemożliwiają bowiem stworzenie płaszczyzny współpracy ${ }^{10}$.

Może jednak się okazać, że to, co dotąd przeszkadzało w integracji Azji, obecnie sprzyja Chinom. Poprzednie inicjatywy w głównej mierze zdeterminowane były decyzjami zachodnich mocarstw, jakże dalszych w każdym aspekcie krajom azjatyckim niż Chiny ${ }^{11}$. Pragmatyczna polityka Pekinu - raczej „defensywne przekonywanie" niż „ofensywne narzucanie” - może doprowadzić w perspektywie, być może nieodległej, do „zbudowania” Azji na nowo, tym razem wokół Chińskiej Republiki Ludowej.

Xi Jinpingowi sprzyja jeszcze jedna, w zasadzie kluczowa kwestia - zgodnie z wyliczeniami ADB Azja potrzebuje 8 bln dolarów na potrzeby rozwoju infrastruktury wewnętrznej oraz 300 mld dolarów dla rozwoju infrastruktury regionalnej w latach 2010-2020. Potrzeby te nie maleją, wręcz z każdym rokiem wzrastają, ADB bowiem inwestuje jedynie około 13 mld dolarów rocznie w nowe projekty infrastrukturalne ${ }^{12}$, a światowa gospodarka nie stoi w miejscu. Wydaje się, że Chiny roku 2017 posiadają już zdolność udźwignięcia ciężaru wiodącej roli na kontynencie i - realizując, co oczywiste, własne ambicje i interesy - rozwijania azjatyckiego rynku w szybszym tempie niż którekolwiek państwo dotychczas.

Ostatni wymiar, międzynarodowy, jest z perspektywy niniejszego artykułu najważniejszy. W nim bowiem rozgrywa się obecnie rozpoczęta kilkanaście lat temu rywalizacja na linii Waszyngton-Pekin. Oddziałuje on również na poprzednie wymiary i w nim realizowane będą chińskie projekty strategiczne - Azjatycki Bank Inwestycji Infrastrukturalnych oraz Nowy Bank Rozwoju. W tej sferze w końcu Chiny upatrują swoją najważniejszą pozycję.

9 Zheng Wang, China's Institution Building..., s. 17.

${ }^{10}$ Dość wspomnieć o dwóch najważniejszych przyczynach: „,wojnie Jiawu” toczonej w latach 1894-1895 z inicjatywy Japonii (w chińskiej historii prezentowana jest jako najdotkliwsza z klęsk. Chińczycy uważają bowiem, w największym uproszczeniu, że to ich cywilizacji Japonia zawdzięcza swoje istnienie. Zob. Peter H. Gries, China's New Nationalism. Pride, Politics and Diplomacy, „University of California Press” 2004, nr 64) oraz tzw. drugiej wojnie japońsko-chińskiej, toczonej w latach 1937-1945, zakończonej bezwarunkową kapitulacją Japonii.

${ }^{11}$ Na przykład w Azjatyckim Banku Rozwoju USA i Japonia posiadają ok. 13\% udziałów, Chiny ok. $6 \%$, a przewodniczy mu zawsze Japończyk; Bankiem Światowym prawie zawsze rządzi Amerykanin; Międzynarodowym Funduszem Walutowym - Europejczyk.

${ }_{12}$ Min Lu, Zhiping Wu, Qingjun Meng, Comprehensive Development Evaluation System of Asian Infrastructure Investment Bank Based on Double Diamond Model, „American Journal of Industrial and Business Management" 2015, nr 5, s. 518-526. 
W 2007 r. na łamach pisma „National Interest” pojawił się artykuł o kontrowersyjnym tytule Świat bez Zachodu. Jego twórcy próbowali dowieść, że czas zachodniej dominacji dobiega końca. Krytycznie odnieśli się również do wykładni amerykańskiej polityki zagranicznej, w której USA podstawę rozwoju procesów światowych upatrują we współpracy z Chinami. Współpracy na zasadach wolnego rynku i idei liberalnych ${ }^{13}$. Siedem lat później ci sami badacze opublikowali niedługi tekst zatytułowany Witamy w świecie bez Zachodu ${ }^{14}$, który miał stanowić potwierdzenie wszystkich postawionych wcześniej tez.

Chiny, zdaniem autorów, według decydentów politycznych w Stanach Zjednoczonych miały do wyboru dwie drogi wyjścia w momencie zahamowania tempa rozwoju: wymienioną wyżej współpracę lub otwartą walkę z największymi potęgami. W momencie publikacji drugiego artykułu, w 2014 r., projekt stworzenia NDB był już pewny, a dyplomacja chińska intensyfikowała wysiłki na rzecz stworzenia AIIB. ChRL nie tylko nie wybrała żadnej z dróg, o których głośno mówiły władze amerykańskie, ale - co najważniejsze - stworzyła własną ${ }^{15}$. Współpraca z najważniejszymi instytucjami kontrolowanymi przez USA została zachowana w dotychczasowej formie i nie rozpoczął się żaden konflikt.

Rywalizacja pomiędzy dwiema największymi gospodarkami świata w wymiarze międzynarodowym koncentruje się obecnie na sile wpływów w regionie Azji i Pacyfiku, a także na obszarze Europy Środkowo-Wschodniej. Dotychczasowa morska dominacja Stanów Zjednoczonych i Japonii w naturalny sposób zagraża rozwojowi Chin. Należy w tym momencie pamiętać o azjatyckich sojusznikach USA położonych na wyspach okalających Chiny i w dalszym ciągu funkcjonujących tam bazach wojskowych, które mają za zadanie stale potwierdzać i zabezpieczać strategiczne punkty morskich szlaków handlowych. Z pozycji Chin nie ma więc w tym momencie innego rozwiązania jak uzyskanie kontroli nad szlakami lądowymi ${ }^{16}$. Budowa Nowego Jedwabnego Szlaku jest zatem wypadkową ścierania się interesów USA w regionie Azji i Pacyfiku oraz w Europie i interesów Chin, targanych skądinąd w dalszym ciągu wewnętrznymi problemami, które ma rozwiązać

${ }_{13}$ Naazneen Barma, Ely Ratner, Steven Weber, A World Without the West, http://nationalinterest. org/article/report-and-retort-a-world-without-the-west-1658 [dostęp 17 maja 2016].

${ }_{14}$ N. Barma, E. Ratner, S. Weber, Welcome to the World Without the West, http://nationalinterest. org/feature/welcome-the-world-without-the-west-11651 [dostęp 12 listopada 2014].

15 Tamże.

${ }^{16}$ Wydaje się, że pełne zastosowanie mają w tym momencie teorie geopolityczne, jakkolwiek krytykowane przez dominujące obecnie neoliberalne i krytyczne podejścia w ,zachodniej” nauce o stosunkach międzynarodowych. Być może właśnie teraz, w całej okazałości ukazuje się potrzeba pogłębionych badań nad wytłumaczeniem powiązań między nadal dobrze obrazującą zachowania państw na arenie międzynarodowej, realistyczną koncepcją geopolityki a liberalnymi koncepcjami współzależności, z neoliberalizmem włącznie, a nawet teoriami krytycznymi. 
budowanie klasy średniej - społeczeństwa konsumpcyjnego. Jednak do tego potrzeba nowego modelu ekonomicznego, którego nie da się zastosować w istniejącym porządku rzeczy.

\section{AllB jako odpowiedź na potrzeby krajów rozwijających się}

Jak już zostało wspomniane, narzędziem w próbie uzyskania kontroli nad lądowymi szlakami handlowymi, poprzez realizację projektu Nowego Jedwabnego Szlaku, jest Azjatycki Bank Inwestycji Infrastrukturalnych. Idea jego stworzenia zrodziła się już pod koniec 2013 r. i obejmowała plany budowy nowego banku w Chinach dla Chin. Z biegiem czasu koncepcja ta zmieniła oblicze na tyle, że ostatecznie członków założycieli jest $57^{17}$ i pochodzą oni niemal z każdego kontynentu. Władze banku 23 marca 2017 r. zaakceptowały wnioski członkowskie 13 nowych państw, co w efekcie podniosło ich liczbę do 70 (stan na wrzesień 2017). W projekcie uczestniczy już 18 krajów członkowskich Unii Europejskiej. W Radzie Dyrektorów funkcje przedstawiciela Polski i alternate director pełni Radosław Pyffel.

Całkowity kapitał własny opiewa na kwotę 100 mld dolarów. Trzy czwarte udziałów w AIIB posiadają państwa azjatyckie, jedną czwartą - spoza Azji ${ }^{18}$ (dokładniej $77,3 \%$ do $22,7 \%$ - stan na wrzesień 2017). Rozwiązanie to, w zamyśle Chin, ma zagłuszyć potencjalny silny głos zachodnich mocarstw, które wbrew oczekiwaniom USA zostały członkami założycielami banku lub zgłosiły chęć akcesji ${ }^{19}$. Ponadto procent udziału uzależniony jest od wielkości PKB danego kraju, co automatycznie stawia Pekin na pozycji głównego udziałowca, z dużą przewagą nad innymi państwami. W perspektywie rozkładu głosów w Radzie Dyrektorów AIIB znaczenie ma wysokość wkładu początkowego. W związku z tym najważniejszymi państwami są: Chiny z 27,52\% głosów, Indie - 7,93\%, Rosja - 6,25\% i Niemcy $-4,37 \%{ }^{20}$.

${ }^{17} \mathrm{~W}$ ich gronie znalazła się również Polska, ratyfikując umowę o utworzeniu Azjatyckiego Banku Inwestycji Infrastrukturalnych ustawą z 11 marca 2016 r.; Ustawa z dnia 11 marca 2016 r. o ratyfikacji Umowy o utworzeniu Azjatyckiego Banku Inwestycji Infrastrukturalnych, sporzadzonej w Pekinie dnia 29 czerwca 2015 r., Dz.U. 2016 poz. 559.

18 J. Szczudlik-Tatar, D. Wnukowski, Azjatycki Bank Inwestycji.., s. 1.

19 Przełomowym momentem było wysłanie dokumentów aplikacyjnych przez Wielką Brytanię, uważaną za największego sojusznika USA w Europie. Niedługo potem swoją aplikację zgłosiły Niemcy, Francja i Włochy, a następnie kolejne 10 państw, również spoza Europy, takich jak Australia czy Korea Południowa.

${ }_{20}$ Members and Prospective Members of the Bank, https://www.aiib.org/en/about-aiib/governance/members-of-bank/index.html [dostęp 4 września 2017]. 
Powstanie AIIB ma dwa podstawowe podłoża: polityczne oraz gospodarcze. Podłoże polityczne ma ścisły związek z regionalnym oraz międzynarodowym wymiarem jakościowej zmiany polityki zagranicznej Chin. Definiuje ono również stanowisko chińskich władz na arenie międzynarodowej jako funkcjonowanie w warunkach niedostatecznego uwzględniania w światowych procesach gospodarczych i finansowych. Stąd też, w opinii Javiera Solany, działania Pekinu nie są rewizjonistyczne, ale reaktywne. Jeśli próby zmiany pozycji w istniejących już strukturach ładu światowego nie przynoszą spodziewanych rezultatów, naturalną konsekwencją - a Chiny mogą sobie na to pozwolić - jest tworzenie własnych struktur ${ }^{21}$.

Stworzenie AIIB określane jest jako największe osiągnięcie ChRL w obszarze ekonomicznych środków soft power ${ }^{22}$. Trudno jednak z tą tezą się zgodzić. Gdyby za punkt wyjścia obrać klasyczną klasyfikację siły stworzoną przez Josepha Nye'a $^{23}$, jej „miękki” wymiar musiałby się opierać na skutecznym przyciąganiu państw do projektów chińskich za pomocą atrakcyjności szeroko pojętej kultury. W tym zbiorze mieszczą się wytwory wszelkich przemysłów kultury, a także godne naśladowania wzorce funkcjonowania państwa, jego instytucji i sfery społecznej. Tego o soft power Chin powiedzieć nie można. Sukces ,przyciągania” przez Pekin państw, również europejskich, jest wynikiem niemal wyłącznie atrakcyjności ekonomicznej i partykularnych interesów tych, którzy w Chinach upatrują nowego globalnego hegemona. Jest to zatem z gruntu działanie w obszarze hard power, jednakże na tyle zawoalowane w formie, że w istocie może wspomóc w perspektywie najbliższych lat budowanie atrakcyjności rozwiązań ChRL, czyli równolegle przeprowadzanych projektów mieszczących się w soft power (na przykład funkcjonowanie ponad 500 Instytutów Konfucjusza na świecie). Mamy więc do czynienia z nową jakością smart power.

Najważniejsze jest w tym momencie podłoże gospodarcze. AIIB jest odpowiedzią na zawodne i niedofinansowane projekty rozwojowe w Azji, tworzone przez ADB, WB czy IMF. Aby ocenić możliwość realizacji celów ekonomicznych Pekinu, należy zarysować możliwości samego AIIB. Pomocne w tym zadaniu będą

${ }^{21}$ Javier Solana, China and Global Governance, https://www.project-syndicate.org/commentary/china-multilateral-institutions-threaten-usby-javier-solana-2015-03 [dostęp 30 marca 2015].

${ }^{22}$ Można uznać, że osiągnięcie to jest bezprecedensowe w skali świata od początków amerykańskiej dominacji, czyli końca XVIII w. Już w 1889 r. kraje Ameryki Łacińskiej wysunęły propozycję stworzenia banku regionalnego, lecz ze względu na sprzeciw USA projekt ten nie mógł być zrealizowany przez ponad 70 lat. Gdy powoływano Afrykański Bank Rozwoju w 1963 r., ze względu na brak akceptacji Waszyngtonu nie były w nim wówczas obecne kraje rozwinięte, co pociągnęło niewielką wartość kapitału własnego. ADB z naczelną rolą Japonii powstał przy wsparciu USA, ze względu na toczącą się wojnę w Wietnamie. Patrz: Robert Withol, Beijing's Challenge to the Global Financial Architecture, „Georgetown Journal of Asian Affairs” 2015, t. 2, nr 1, s. 13. Natomiast Pekin stworzył AIIB i włączył w swój projekt 70 krajów świata bez akceptacji USA i mimo ich głosów sprzeciwu.

${ }^{23}$ Joseph S. Nye Jr., Soft Power: The Means to Success in World Politics, „Public Affairs” 2004. 
analizy naukowców z Hohai University w Chinach, które opierają się na narzędziu Double diamond mode ${ }^{24}$. Na bazie założeń modelu wyróżnili cztery główne obszary.

1. Zdolność, pojmowana jako zarządzanie finansami i poziom obserwacji inwestycyjnych. Chiny nie mają dużego doświadczenia w tym obszarze, a sytuację komplikuje fakt, że większość członków AIIB to kraje rozwijające się, a więc stopień otwartości sektora finansowego jest na relatywnie niskim poziomie. W tym sensie trudno będzie Chinom zdobyć pełne zaufanie krajów rozwiniętych do jakości zarządzania finansowego. Ponadto zakładane projekty banku skupiają się głównie na terenach o długich cyklach inwestycyjnych, w krajach cechujących się dużą niestabilnością polityczną. To z kolei przekłada się na ryzyko braku spłat kredytów udzielanych przez AIIB. $\mathrm{Z}$ tym problemem od lat borykają się WB, ADB oraz IMF.

2. Czynniki produkcji, w przypadku AIIB najważniejszy z nich to kapitał. Wspomniana już wcześniej kwota 100 mld dolarów, choć wydaje się imponująca, w porównaniu z początkowym kapitałem ADB - 160 mld euro (1968) i ogłoszoną przez Japonię w ostatnim czasie pomocą skierowaną do państw rozwijających się na obszarze Azji, w wysokości 110 mld dolarów, może nie zadziałać mobilizująco. Jednak rozmach zarówno w liczbie członków, jak i w obszarze oraz ogromne rezerwy finansowe Chin skłaniają ku tezie o wysokich możliwościach operacyjnych tej kwoty, a nawet o zwiększeniu jej w momencie zaistnienia takiej potrzeby.

3. Czynniki popytowe. W tym obszarze nie ma wątpliwości co do słuszności powstania AIIB. Wspomniane wcześniej 8 bln dolarów potrzeb inwestycyjnych w Azji, które stale rosną, generuje odpowiedni poziom popytu w niemal każdej gałęzi gospodarki.

4. Wsparcie przemysłu. Dominującą kwestią jest przemysł chiński. Według ostatnich statystyk Banku Światowego w 2013 r. w handlu towarami (w tym z rynku rolnictwa, paliw i minerałów oraz wyrobów gotowych) wskaźnik eksportu produkcji przemysłowej osiągnął 94,09\% wielkości całej sprzedaży za granicę. Chińskie firmy stają się coraz bardziej rozpoznawalne i wykazują stale polepszającą się jakość ${ }^{25}$.

${ }^{24}$ Model ekonomiczny stworzony przez Michaela Portera i opublikowany w 1998 r. w książce The Competitive Advantage of Nations. Za pomocą modelu Porter próbował wyjaśnić, dlaczego poszczególne gałęzie przemysłu stają się konkurencyjne w określonych lokalizacjach. Patrz: Michael E. Porter, The Competitive Advantage of Nations, Free Press, New York 1998.

${ }^{25}$ Min Lu, Zhiping Wu, Qingjun Meng, Comprehensive Development..., s. 518-526. 
Dla dopełnienia ustalono także dwa obszary pomocnicze.

1. Strategia biznesowa, struktura i konkurencja. Jako międzyrządowa agencja rozwoju regionalnego $\mathrm{ADB}$ ma przede wszystkim na celu pomoc $\mathrm{w}$ rozwoju państw w regionie Azji i Pacyfiku, ukierunkowaną na wyeliminowanie ubóstwa oraz promowanie rozwoju gospodarczego i społecznego poprzez pomoc między innymi w dziedzinie infrastruktury, energetyki, ochrony środowiska, edukacji i zdrowia. $Z$ tego punktu widzenia istnieje podobieństwo między AIIB i ADB. Jednak podstawową różnicą w modelu biznesowym AIIB jest promowanie wybitnych talentów menedżerskich poprzez fakt, że Rada Dyrektorów AIIB nie będzie pobierała wynagrodzenia za swoją pracę. Zapis o tym znalazł się w Karcie AIIB. Jeśli członkowie zgodzą się go utrzymać, może on stworzyć nowy paradygmat rozwoju instytucji wielostronnych, wspierać reformę strukturalną ich zarządzania oraz poprawić globalny wzorzec ${ }^{26}$.

2. Szanse i rola rządu. Choć wysiłki chińskich dyplomatów w uzyskaniu większego wpływu na światowe instytucje finansowe są imponujące, to efekty tego są niewielkie. Punkt ten wpisuje się w wyszczególnione wcześniej reaktywne powody działania Pekinu.

Wśród wymienionych obszarów dla przyszłej efektywności AIIB, czyli realizacji inwestycji infrastrukturalnych na obszarze Azji oraz dalej - w Europie Środkowo-Wschodniej, a także w konsekwencji osiągnięcie celu, jakim wydaje się przebudowanie światowej architektury finansowej, najistotniejsza jest właśnie jakość zarządzania finansowego AIIB. Podobnie jak inne instytucje finansowe bank ten będzie zbierać fundusze dla swoich pożyczek na międzynarodowym rynku finansowym. Niezbędne w tym obszarze było stworzenie poczucia stabilności i zaufania największych graczy w tym sektorze, poparte wysokimi wskaźnikami ratingu kredytowego. Agencje ratingowe nie tylko oceniają zarządzanie finansami, ale i profil działalności, w tym politykę zarządzania ryzykiem ${ }^{27}$. Pierwszym sukcesem w tym obszarze była najwyższa ocena wiarygodności kredytowej AIIB wystawiona przez agencję Moody's - AAA, 29 czerwca 2017 r. ${ }^{28}$ Dwa tygodnie później, 13 lipca, kolejna agencja - Fitch - również wystawiła najwyższą ocenę ${ }^{29}$, a pięć dni później AAA przyznało S\&P $\mathrm{P}^{30}$. AIIB, uznawany początkowo za eksperyment, który

26 Tamże.

${ }^{27}$ R. Withol, Beijing's Challenge..., s. 13.

${ }_{28}$ AIIB Receives Triple-A Credit Rating, https://www.aiib.org/en/news-events/news/2017/ 20170629 001.html [dostęp 3 września 2017].

${ }_{29}$ AIIB Receives Second Triple-A Credit Rating, https://www.aiib.org/en/news-events/news/2017/ 20170713_001.html [dostęp 3 września 2017].

${ }_{30}$ AIIB Receives Third Triple-A Credit Rating, https://www.aiib.org/en/news-events/news/2017/ 20170718_001.html [dostęp 3 września 2017]. 
nie musi się zakończyć powodzeniem, w oczach zachodnich inwestorów stał się wysoce bezpieczną instytucją z dobrymi perspektywami rozwoju.

Opierając się na niezwykle skrupulatnej analizie biznesowej AIIB, autorstwa profesorów południowokoreańskiej KDI School, można wskazać następujące priorytety działania $\mathrm{w}$ ciągu najbliższych pięciu lat:

- rozwijanie preferencyjnych obszarów finansowania, stworzenie rozsądnych progów pomocowych i zróżnicowanych stóp procentowych dla ułatwienia prawidłowego rozdysponowania funduszy rozwojowych;

- inwestowanie w równym stopniu w projekty inwestycyjne, jak i w instrumenty finansowe dla istniejących już projektów infrastrukturalnych;

- bezpośrednie inwestycje AIIB w projekty infrastrukturalne powinny się koncentrować na kapitale własnym, długach podporządkowanych i gwarancjach, a nie na długach uprzywilejowanych;

- AIIB powinno również skupić się na przyciągnięciu współinwestorów z sektora funduszy emerytalnych, firm ubezpieczeniowych i państwowych funduszy majątkowych ${ }^{31}$.

Choć obecnie jest stanowczo za wcześnie na ocenę skuteczności prowadzonych działań w ramach zadań priorytetowych banku, warto zauważyć widoczną już teraz tendencję szybkości rozwoju. W 2016 r. zakontraktowano dziewięć projektów na łączną kwotę 1,73 mld dolarów, przy czym wszystkie odnoszą się do kontynentu azjatyckiego, w tym głównie do państw biednych i najsłabiej rozwiniętych: Omanu, Tadżykistanu, Bangladeszu czy Mjanmy/Birmy. Nie są to projekty w całości finansowane przez AIIB, lecz w ścisłej kooperacji z Bankiem Światowym (pięć projektów), Europejskim Bankiem Odbudowy i Rozwoju (jeden projekt) oraz Nowym Bankiem Rozwoju (dwa projekty). Tylko jeden projekt jest kredytem bezpośrednim, udzielonym Mjanmie/Birmie ${ }^{32}$. Natomiast do września 2017 r. zaakceptowano finansowanie 19 projektów w kwocie ok. 1,3 mld dolarów (łączna wartość projektów wynosi ok. 4,6 mld dolarów) ${ }^{33}$.

\section{Wschodzące gospodarki łączq̣ siły}

AIIB to niejedyny wielki projekt, którego inicjatorami są Chiny. Drugim, nie mniej ważnym, jest Nowy Bank Rozwoju (NDB), utworzony 15 lipca 2014 r.

${ }^{31}$ Patrz: Wonhyuk Lim, Wiliam P. Mako, AIIB Business Strategy Decisions: What It Can Do Differently to Make a Difference, KDI School Working Paper Series, 2015, nr 15-04.

32 Approved Projects, https://www.aiib.org/en/projects/approved/index.html [dostęp 4 września 2017].

33 Tamże. 
w ramach BRICS ${ }^{34}$, jako efekt szczytu przywódców ugrupowania w brazylijskim mieście Fortaleza. Początkowy kapitał banku ma wynosić 50 mld dolarów, a docelowy 100 mld dolarów. Do udziału w tworzeniu Nowego Banku Rozwoju zaproszone zostały również kraje spoza BRICS, jednak przy zastrzeżeniu ponad 50\% udziałów dla Brazylii, Rosji, Indii, Chin i RPA ${ }^{35}$. Zastrzeżenie o pakiecie większościowym jest kluczowe, stanowi bowiem kolejny przykład nie tylko próby zmiany dotychczasowego porządku światowego dokonywanej przez Chiny, ale również przez pozostałe największe gospodarki wschodzące.

Jednym z podstawowych zagadnień poruszanych przez światowych ekspertów jest swoisty fenomen dojścia do wspólnego stanowiska przez państwa, które zasadniczo więcej dzieli, niż łączy, a najlepszym przykładem tego są choćby problemy terytorialne w relacjach chińsko-indyjskich ${ }^{36}$. Problem ów nie dotyczy jednak tylko newralgicznych terytoriów, ale również konfrontacji o dominację w regionie, w tym oczywiście dominację gospodarczą, jako szczególnie ważną. Ponadto Brazylia, choć oddalona od Chin o wiele tysięcy kilometrów, z niepokojem obserwuje rosnącą potęgę dyplomatyczną Pekinu i stopniowe realizowanie analizowanego celu. Rosji jako pretendentowi do roli mocarstwa regionalnego również nie powinno zależeć na rozszerzaniu globalnych wpływów Chin, choćby ze względu na jej azjatyckie interesy ${ }^{37}$. Wydaje się zatem, że w myśl realistycznej koncepcji Johna Mearsheimera państwa te, walcząc o relatywnie największe zyski, nie powinny być skłonne do współpracy ${ }^{38}$.

Stało się jednak zgoła inaczej i wystarczyło do tego jedynie sześć szczytów. Oficjalne powody zawiązania ścisłej współpracy są różne, nie zawsze przekonujące. Podkreśla się czynniki ideologiczne i historyczne, takie jak kolonialna spuścizna wszystkich prócz Rosji ${ }^{39}$ członków BRICS oraz solidarność gospodarek

34 Tomasz Rudowski, Gospodarka, „Ameryka Łacińska” 2014, nr 3-4 (85-86), s. 119.

35 Эндрю Ф. Купер, Асиф Б. Фарук, Апробация клубного механизма взаимодействия БРИКС: Новый банк развития от концепции до становления, „Вестник международных организаций: образование, наука, новая экономика" 2015, t. 10, nr 2, s. 39-40.

36 „Problem granicy między Chinami a Indiami istnieje w regionie od końca XIX wieku i można uznać go za dziedzictwo kolonialnych rządów Brytyjczyków”; Łukasz Wielogórski, Granica przyjaźni chińsko-indyjskiej, http://www.psz.pl/123-bezpieczenstwo/granica-przyjazni-czyli-dlaczego-indie-i-chiny-nie-chca-rozwiazac-sporu-granicznego [dostęp 27 marca 2015].

37 Andrew F. Cooper, Asif B. Farooq, Testing the Club Dynamics of the BRICS: The New Development Bank from Conception to Establishment, „International Organisations Research Journal” 2015 , t. 10 , nr 2, s. 32-33.

${ }^{38}$ Por. John J. Mearsheimer, The False Promise of International Institutions, „Internationl Security" 1994/1995, t. 19, nr 3.

39 O przemożnym wpływie kolonializmu na dzisiejsze wydarzenia globalne błyskotliwie pisze Mariusz Agnosiewicz: „Afryka też w końcu się otrząśnie z postkolonialnych zależności i elit. (...) Jeśli Unia Afrykańska nawiąże współpracę z Chinami, może dojść do gwałtownej modernizacji i rozwoju. 
wschodzących, oparta na zależnościach Południe-Południe ${ }^{40}$. Ponadto współpraca ugrupowania przy pomocy NDB uznawana jest za kierunek konieczny dla poprawy sytuacji państw rozwijających się, opartej na rozwoju infrastruktury ${ }^{41}$ (podobnie jak w przypadku AIIB). Powstaje więc pytanie, czy powyższe są wystarczającymi determinantami zmiany nieformalnego ugrupowania, którego transparentność uzgodnień nie istniała, $\mathrm{w}$ istocie $\mathrm{w}$ zinstytucjonalizowane stowarzyszenie ${ }^{42} \mathrm{z}$ własnym dużym bankiem. Czy może porzucenie większości barier w relacjach oznacza świadomość dokonującej się już teraz wielkiej zmiany w światowej architekturze, a w wyłaniającym się nowym porządku Stany Zjednoczone nie będą mocarstwem dominującym?

Odpowiedzi na te pytania padną prawdopodobnie w ciągu najbliższych kilkunastu lat. Ich przesłanką jest jednak funkcjonowanie Nowego Banku Rozwoju, które za Stephany Griffith-Jones można przedstawić w pięciu najważniejszych obszarach:

1. Nakłady infrastrukturalne krajów rozwijających się. Fakt, że niezaspokojone potrzeby w zakresie infrastruktury i zrównoważonego rozwoju są bardzo duże i że taka inwestycja jest kluczowa dla wzrostu sprzyjającego przeciwdziałaniu wykluczeniu społecznemu, uzasadnia decyzję przywódców BRICS skupienia się na działalność NDB w tym obszarze. Oznacza to, że skala akcji kredytowej banku BRICS musi być na tyle duża, aby wywrzeć znaczący wpływ. Ponadto wpływ banku BRICS należy mierzyć pod względem jego zdolności do współfinansowania projektów z sektora prywatnego i publicznego.

2. Kredyty. Ważną kwestią jest jakość udzielanych kredytów. Zaistnieć musi kompromis między szybkością wzrostu portfela kredytów i ich jakością. Choć skala jest oczywiście ważna, wysoka jakość kredytów jest priorytetem,

W przeciwieństwie bowiem do potęg postkolonialnych, które udają, że pomagają się Afryce rozwijać, Chiny nie mają powodów, by obawiać się dynamicznego rozwoju Afryki. Potęgi postkolonialne mają powody, by się tego obawiać, bo wraz z modernizacją pojawi się pogłębiona refleksja historyczna, która przypomni i opisze wszystkie mechanizmy kolonialne”. Mariusz Agnosiewicz, Holokausty kolonialne. Krwawe bogactwo i rozpad tożsamości Zachodu, http://www.racjonalista.pl/ kk.php/s,10007 [dostęp 27 maja 2016].

${ }^{40}$ A.F. Cooper, A.B. Farooq, Testing the Club Dynamics..., s. 35.

${ }^{41}$ Poparcie akurat tego argumentu jest mocne: 1,4 mld ludzi nie ma dostępu do elektryczności, 0,9 mld ludzi nie ma dostępu do czystej wody pitnej i 2,6 mld nie ma dostępu do urządzeń sanitarnych. Por. Stephany Griffith-Jones, A Brics Development Bank: A Dream Coming True?, „UNCTAD Discussion Papers" 2014, nr 215.

${ }^{42}$ Szerzej o konieczności instytucjonalizacji w celu możliwości skutecznego realizowania celów NBR: Э.П. Джагитян, Институционализачия экономического механизма группы БРИКС: преимущества и риски Нового банка развития, „Деньги и Кредит” 2015, nr 6, s. 29-30. Perspektywa rosyjskich ekspertów jest o tyle ciekawa, że dotąd Rosja nie wykazywała chęci pogłębionej instytucjonalizacji w ramach BRICS. 
gdyż maksymalizuje prawdopodobny wpływ na rozwój projektów i minimalizuje ryzyko niewypłacalności kredytów - a to z kolei warunkuje rating kredytowy banku BRICS.

3. Zasięg geograficzny kredytów. Wydaje się pożądane dla wiarygodności banku BRICS, aby stworzyć zrównoważony portfel kredytów, który obejmie kraje z różnych regionów, zarówno o średnich, jak i niskich dochodach. Afryka Subsaharyjska w naturalny sposób będzie więc głównym kredytobiorcą, choć nie można oczekiwać, że kredyty udzielane będą na zasadach dotacji.

4. Zarządzanie kapitałem. Choć kapitał docelowy ma wynieść $100 \mathrm{mld}$ dolarów, w początkowej fazie uzgodniono wpłacenie 10 mld dolarów, z czego najwięcej wniosą Chiny. Operacje kredytowe muszą być więc dostosowane do wartości początkowej, aby zapewnić płynność finansową i zyski z pożyczanych pieniędzy w perspektywie długoterminowej. Wydaje się, że na początku największą odpowiedzialność (oraz największe straty) za prowadzenie NDB będą ponosić Chiny.

5. Współpraca $z$ istniejącymi strukturami finansowymi. NDB może początkowo korzystać z doświadczenia i wiedzy istniejących banków rozwoju, jak CAF i EBI na poziomie regionalnym, i na przykład brazylijskiego Banco Nacional de Desenvolvimento Econômico e Social (BNDES), niemieckiego Kreditanstalt für Wiederaufbau (KfW), południowoafrykańskiego South African Industrial Development Corporation, jak również innych. Na późniejszym etapie NDB może odgrywać ważną rolę w umacnianiu, a także we współpracy z krajowymi i regionalnymi bankami rozwoju, zwłaszcza w Afryce Subsaharyjskiej ${ }^{43}$.

Już w 2001 r. jeden z najbardziej wpływowych pracowników Goldman Sachs, Jim O'Neil, pisał, że w ciągu 10 lat waga BRIC (RPA dołączyła do grupy w 2011 r., stąd w 2001 r. O’Neil posługiwał się skrótem BRIC, choć praktyka ta kontynuowana jest przez wielu ekspertów do dziś), a zwłaszcza Chin w światowym PKB wzrośnie, podnosząc ważne kwestie dotyczące globalnego ekonomicznego wpływu polityki fiskalnej i monetarnej ${ }^{44}$. O ile w 2011 r. rzeczywiście rola Chińskiej Republiki Ludowej wzrosła do rozmiarów niebagatelnych, to w 2017 r. niewielu już chyba stawia tezę, w myśl której państwo to jest kolosem na glinianych nogach. Na jej niekorzyść przemawia rzeczywistość. We wrześniu 2016 r. osiągnięty został najważniejszy bodaj cel chińskiej partii w sferze finansowej - juan (renminbi, RMB) został piątą rezerwową walutą świata w koszyku SDR, z udziałem 10,92\%, co

43 Patrz: tamże.

${ }^{44}$ Valeria Rohde, BRICS and the New Development Bank: Impact on the U.S. Economy and the Dollar, „A with Honors Projects” 2015, nr 145. 
sytuuje ją na trzecim miejscu, po dolarze amerykańskim $(41,73 \%)$ i euro $(30,93 \%)$, a przed jenem japońskim $(8,33 \%)$ i funtem szterlingiem $(8,09 \%)^{45}$.

Pociąga to za sobą większą elastyczność rozliczeń zawieranych przez Chiny kontraktów. Już od lat Pekin sukcesywnie stara się używać w tym celu juana zamiast dolara. We wrześniu 2017 r. ogłoszono, że w najbliższym czasie uruchomiony zostanie rynek kontraktów terminowych na ropę naftową rozliczanych w juanie. Ponadto zadeklarowano pełną wymienialność waluty na złoto na giełdach w Szanghaju i Hongkongu ${ }^{46}$. Po pierwsze, jest to zapowiedź kolejnego etapu kreowania niejako „drugiego obiegu” rozliczeń, podnoszących znaczenie waluty chińskiej, umniejszając tym samym wpływy amerykańskie na globalne przepływy walutowe. Po drugie, jest to zachwianie w posadach hegemonicznych działań USA i UE w sferze gospodarczej i politycznej. Stworzy to bowiem większe możliwości ominięcia, z wykorzystaniem juana, sankcji ekonomicznych nakładanych przez te dwa podmioty. Automatycznie spadnie nie tylko ich realna siła oddziaływania gospodarczego, ale przede wszystkim - politycznego. O ile USA, realizując założenia koncepcji smart power, posiadają wachlarz argumentów poza sankcjami, UE jest w tym obszarze niemal bezradna. W stosunku do Chin dyrektywy i apele na forum Parlamentu Europejskiego z pewnością nie okażą się skuteczne.

Wpisuje się to również w koncepcję toczącej się obecnie wojny walutowej, której głównymi graczami są nie tylko USA i Chiny, ale i Rosja, która w ciągu ostatnich lat w rozliczeniach ropy naftowej również zaczyna używać rubla ${ }^{47}$. Nowy Bank Rozwoju może stanowić, wraz z AIIB, idealną podstawę dla wzrostu znaczenia chińskiej waluty w międzynarodowych rozliczeniach finansowych. $Z$ drugiej strony, nie może się to dziać za szybko, wartość amerykańskich obligacji w ChRL wynosi bowiem, bagatela, około 1,3 bln dolarów ${ }^{48}$. Mocne osłabienie dolara amerykańskiego znacznie zuboży posiadane przez Chiny rezerwy.

45 Tomasz Gruszecki, Juan wychodzi z cienia, wchodzi do koszyka SDR, https://www.obserwatorfinansowy.pl/tematyka/rynki-finansowe/yuan-wychodzi-z-cienia-wchodzi-do-koszyka-sdr/ [dostęp 15 września 2016].

${ }^{46}$ Damon Evans, China Sees New World Order with Oil Benchmark Backed by Gold, https:// asia.nikkei.com/Markets/Commodities/China-sees-new-world-order-with-oil-benchmark-backed-by-gold [dostęp 1 września 2017].

${ }^{47}$ Szerzej o zjawisku wojny walutowej: Adam Lelonek, Nowa faza wojny walutowej. Nadchodzi papierowa Apokalipsa?, http://www.psz.pl/124-polityka/adam-lelonek-nowa-faza-wojny-walutowej-nadchodzi-papierowa-apokalipsa [dostęp 18 stycznia 2013].

${ }^{48} \mathrm{~W}$ połowie 2015 r. pojawiła się informacja, że Chiny wyprzedają amerykańskie obligacje. Do obiegu miało trafić 106 mld; Michał Żuławiński, Chiny sprzedały obligacje USA?, http://www.bankier.pl/wiadomosc/Chiny-sprzedaly-obligacje-USA-7275798.html [dostęp 28 sierpnia 2015]. 


\section{Wnioski}

Obecne przeobrażenia światowej architektury gospodarczej i finansowej są już tak wyraźne, że nie sposób nie uwzględniać ich w analizach dotyczących funkcjonowania i rozwoju zarówno poszczególnych państw, jak i najważniejszych instytucji. AIIB oraz NDB powinny stanowić punkty wyjścia dla zrozumienia procesów nie w pełni jeszcze rozumianych w perspektywie dostępnych teorii czy modeli w nauce o stosunkach międzynarodowych. Chiny jednoznacznie dążą do osiągnięcia pozycji mocarstwa dorównującego we wszelkich aspektach Stanom Zjednoczonym, czego najlepszym potwierdzeniem wydają się dwa globalne, bardzo ambitne projekty Pekinu. Na tym etapie przydatna w wytłumaczeniu chińskich motywów jest koncepcja geopolityki, uzupełniona aspektami ekonomicznymi. Uzyskanie dominacji nad lądowymi szlakami handlowymi i komunikacyjnymi zapewni Państwu Środka odpowiednie zaplecze infrastrukturalne oraz może zapewnić akceptację społeczności międzynarodowej dla dalszych kroków. Odpowiedź na pytanie, jakie będą owe kroki, stanie się kluczowa dla każdego z państw i każdej z korporacji transnarodowych. Choć nie wolno zapominać o najważniejszym problemie Chińczyków - utrzymaniu odpowiedniego tempa nie tylko wzrostu gospodarczego, ale również rozwoju.

Summary

\section{AIIB and NDB - the foundations of the geopolitical strategy of the People's Republic of China}

The end of the second decade of the 20th century, as predicted by many commentators of world political stage will be also the beginning of end of a global governance, formed after the end of the Cold War. In recent years, as demonstrated by the 2007/2008 financial crisis, Washington no longer has tools powerful enough to unanimously design economic architecture of the world. In 2015, for the first time since 19th century, the indisputable dominance of the US in economic sphere has been upset - Beijing managed to come out on first place in terms of GDP (PPPs).

The time of Chinese prosperity based on cheap production and export of cheap goods is coming to an end. To ensure further dynamic development, it will be necessary to gain control over the continental trade. 
At least until the end of US sea domination. For this to happen, further weakening of the position of Washington, by gradually taking control over global financial and foreign exchange market will be necessary. The article is to verify the hypothesis, according to which People's Republic of China using two strategic institutions - the Asian Infrastructure Investment Bank (AIIB) and the New Development Bank (NDB) can achieve economic dominance overland. It was necessary to define the basic presuppositions: there will be no open armed conflict on a global scale over several consecutive years; there will be no political crisis in China; United States won't give up the domination of the sea trade routes; there will be no reorientation of US foreign policy in a way that could undermine the existing institutional frameworks in the financial and economic sphere.

\section{Bibliografia}

6. AIIB Receives Second Triple-A Credit Rating, https://www.aiib.org/en/news-events/news/2017/20170713_001.html.

7. AIIB Receives Third Triple-A Credit Rating, https://www.aiib.org/en/news-events/news/2017/20170718_001.html.

8. AIIB Receives Triple-A Credit Rating, https://www.aiib.org/en/news-events/ news/2017/20170629_001.html.

9. Approved Projects, https://www.aiib.org/en/projects/approved/index.html.

10. Barma N., Ratner E., Weber S., A World Without the West, http://nationalinterest. org/article/report-and-retort-a-world-without-the-west-1658.

11. Barma N., Ratner E., Weber S., Welcome to the World Without the West, http:// nationalinterest.org/feature/welcome-the-world-without-the-west-11651.

12. Cooper A.F., Farooq A.B., Testing the Club Dynamics of the BRICS: The New Development Bank from Conception to Establishment, ,International Organisations Research Journal" 2015, t. 10, nr 2.

13. Ekman A., China: Setting the Agenda(s)?, European Union Institute for Security Studies, „Issue Brief” 2015, nr 4.

14. Evans D., China Sees New World Order with Oil Benchmark Backed by Gold, https://asia.nikkei.com/Markets/Commodities/China-sees-new-world-order-with-oil-benchmark-backed-by-gold.

15. Góralczyk B., Geostrategia energetyczna Chin, http://cse.ibngr.pl/geostrategia-energetyczna-chin. 
16. Gries P.H., China 's New Nationalism. Pride, Politics and Diplomacy, „University of California Press" 2004, nr 64.

17. Gruszecki T., Juan wychodzi z cienia, wchodzi do koszyka SDR, https://www. obserwa- torfinansowy.pl/tematyka/rynki-finansowe/yuan-wychodzi-z-cienia-wchodzi-do-koszyka-sdr/.

18. Huntington S.P., Zderzenie cywilizacji i nowy kształt ładu światowego, przekł. H. Janowska, Warszawa 2006.

19. Koneczny F., O ład w historii, Warszawa 1991.

20. Lelonek A., Nowa faza wojny walutowej. Nadchodzi papierowa Apokalipsa?, http://www.psz.pl/124-polityka/adam-lelonek-nowa-faza-wojny-walu-towej-nadchodzi-papierowa-apokalipsa.

21. Mearsheimer J.J., The False Promise of International Institutions, „Internationl Security" 1994/1995, t. 19, nr 3.

22. Members and Prospective Members of the Bank, https://www.aiib.org/en/about-aiib/governance/members-of-bank/index.html.

23. Michael E. Porter, The Competitive Advantage of Nations, New York 1998.

24. Min Lu, Zhiping Wu, Qingjun Meng, Comprehensive Development Evaluation System of Asian Infrastructure Investment Bank Based on Double Diamond Model, „American Journal of Industrial Business Management” 2015, nr 5.

25. Nye Jr. J.S., Soft Power: The Means to Success in World Politics, „Public Affairs" 2004.

26. Rezerwy walutowe Chin wzrosty najmocniej od 3 lat, https://www.bankier.pl/ wiadomosc/Re-zerwy-walutowe-Chin-wzrosly-najmocniej-od-3-lat-7515521. html.

27. Rohde V., BRICS and the New Development Bank: Impact on the U.S. Economy and the Dollar, „A with Honors Projects” 2015, nr 145.

28. Rudowski T., Gospodarka, „Ameryka Łacińska” 2014, nr 3-4 (85-86).

29. Solana J., China and Global Governance, https://www.project-syndicate. org/commen- tary/china-multilateral-institutions-threaten-usby-javier-solana-2015-03.

30. Sulmicki J., Chiny umacniaja dominująca pozycję w gospodarce światowej, „Zeszyty Naukowe Akademii Vistula" 2015, nr 43 (3).

31. Szczudlik-Tatar J., Wnukowski D., Azjatycki Bank Inwestycji Infrastrukturalnych: szanse dla polskiego biznesu, „Biuletyn PISM” 2015, nr 52 (1289).

32. Wielogórski Ł., Granica przyjaźni chińsko-indyjskiej, http://www.psz.pl/ 123-bezpieczenstwo/granica-przyjazni-czyli-dlaczego-indie-i-chiny-nie-chca-rozwiazac-sporu-granicznego.

33. Withol R., Beijing 's Challenge to the Global Financial Architecture, „Georgetown Journal of Asian Affairs" 2015, t. 2, nr 1. 
34. Wonhyuk Lim, Mako W.P., AIIB Business Strategy Decisions: What It Can Do Differently to Make a Difference, KDI School Working Paper Series, 2015, nr 15-04.

35. Zheng Wang, China's Institution Building. Leading the Way to Asian Integration, „Georgetown Journal of Asian Affairs”, Spring/Summer 2015.

36. Żuławiński M., Chiny sprzedały obligacje USA?, http://www.ban-kier.pl/wiadomosc/Chiny-sprzedaly-obligacje-USA-7275798.html.

37. Джагитян Э.П., Институционализация экономического механизма группь БРИКС: преимущества и риски Нового банка развития, „Деньги и Кредит” 2015, nr 6.

38. Купер ЭФ., Фарук А.Б., Апробаџия клубного механизма взаимодействия БРИКС: Новый банк развития от концепщии до становления, „Вестник международных организаций: образование, наука, новая экономика" 2015, t. 10, nr 2 . 